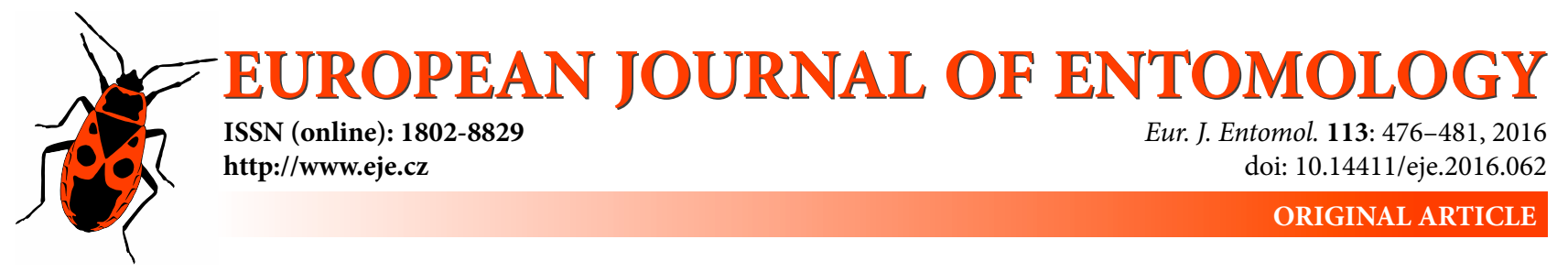

\title{
Assessment of the quality of the terrestrial habitat of the threatened dragonfly, Sympetrum depressiusculum (Odonata: Libellulidae)
}

\author{
MICHAL HYKEL ${ }^{1}$, FILIP HARABIŠ ${ }^{2}$ and ALEš DOLNÝ ${ }^{1}$ \\ ${ }^{1}$ Department of Biology and Ecology / Institute of Environmental Technologies, Faculty of Science, University of Ostrava, \\ Chittussiho 10, CZ-710 00 Slezská Ostrava, Czech Republic; e-mails: michalhykel@seznam.cz, ales.dolny@osu.cz \\ ${ }^{2}$ Department of Ecology, Faculty of Environmental Sciences, Czech University of Life Sciences Prague, Kamýcká 129, \\ CZ-165 21 Prague 6, Czech Republic; e-mail: harabis.f@gmail.com
}

Key words. Odonata, Libellulidae, Sympetrum depressiusculum, aquatic insect, endangered species, habitat preference, habitat management, terrestrial environment, landscape heterogeneity

\begin{abstract}
The majority of the conservation strategies for threatened dragonflies are designed to protect only their aquatic habitats. Sympetrum depressiusculum is a species threatened not only by the destruction of its aquatic habitats but also by its association with a specific terrestrial environment. In this study, we aimed to identify the key elements of the terrestrial environment of adult S. depressiusculum. We used generalized linear mixed models to determine habitat preferences of adults and the particular features of habitat patches, such as vegetation cover, vegetation structure and the availability of potential prey. Our results indicate that $S$. depressiusculum adults preferred mainly riparian vegetation but beyond ponds they utilized only certain terrestrial habitats (abandoned fields, meadows, forest clearings). Adults responded positively to habitat patches with a high cover of vegetation and suitable vegetation structure. Adult abundance was affected also by the distance of patches from the natal site. In an agricultural landscape, the availability of such habitat patches may be limited and could influence the abundance and distribution of this species. We suggest that conservation efforts for this species should not only focus on the larval environment but also include suitable surrounding terrestrial habitats. Effective management around natal sites should concentrate on maintaining a heterogeneous landscape, which is extensively managed (e.g. leaving several fields fallow, maintaining managed hay meadows).
\end{abstract}

\section{INTRODUCTION}

A suitable environment for an animal includes a mosaic of habitat patches that are suitable for all the activities essential for successful reproduction and population persistence (Orians \& Wittenberger, 1991). It should be emphasized that the complex habitats of odonate species must meet these ecological requirements at all stages of their life cycle (Corbet, 1999). Moreover, responses to a stressful environment at any stage may carry over and shape fitness in subsequent stages and generations (Stoks \& CórdobaAguilar, 2012).

Adult dragonflies and damselflies in terrestrial environments use various habitat patches for mating, perching, foraging and nocturnal roosting (Corbet, 1999; Kirkton \& Schultz, 2001; Rouquette \& Thompson, 2007; Wildermuth, 2012). In addition, occurrence of adult odonates outside aquatic habitats may be associated with their dispersal (Suhling et al., 2015), and this may be influenced by landscape structure (e.g. Watts et al., 2004). The value of a high dispersal ability is important especially for those species occurring in patchy isolated habitats (e.g. ponds surrounded by a homogeneous agricultural landscape), mainly be- cause it has a major effect on their population dynamics (Angelibert \& Giani, 2003).

Conservation of species threatened by habitat loss and habitat degradation is predominantly based on a knowledge of their habitat preferences and the factors that significantly sustain their occurrence (Moore, 1997; Allen et al., 2010). Nevertheless, little attention has been given to the role of terrestrial habitats for adult odonates (Rouquette \& Thompson, 2007; Dolný et al., 2014). Although it is assumed that adults respond very sensitively to land use practices around wetlands (D’Amico et al., 2004; Dolný et al., 2012; Kutcher \& Bried, 2014), the majority of the conservation strategies for threatened dragonfly species are designed only to protect larval habitats (Dolný et al., 2014). Similarly, most studies addressing factors that affect the occurrence of adults focus on the immediate surroundings of their aquatic habitats (e.g. Raab et al., 1996; Ward \& Mill, 2005).

Due to the destruction of its aquatic habitat, Sympetrum depressiusculum (Selys) has declined sharply in abundance in the past century and, in contrast to many other European species, this decline is still continuing (Kalkman \& 
Conze, 2015). This species is associated with ephemeral habitats and spends a considerable part of its adult life cycle outside aquatic environments. Larval development lasts less than two months, while some adult individuals (the oldest specimen) live for almost 2 months (Raab et al., 2007; Dolný et al., 2014). Close association with terrestrial habitats in this species is therefore inevitably significantly more important than for species associated with permanent habitats. The findings of Dolný et al. (2014) indicate that the preference of $S$. depressiusculum adults for specific terrestrial habitats is not random, but determined by adults preferring only certain types of habitat, such as abandoned fields and small areas of ruderals. Unfortunately, that study does not convincingly determine which ecological factors affect the habitat preferences and use of terrestrial habitats by adult odonates' for their daily activities. Consequently, it is not known which specific management actions must be taken to protect such threatened species. Therefore, we present here the results of a study of adult preferences for specific types of terrestrial habitats. We hypothesized that the preference for particular terrestrial habitats is primarily determined by the availability of shelter and food, which are mainly associated with the type and structure of the vegetation. However, we must also include the effect of distance from the natal site, which could significantly affect the number of adults finding these habitats. We therefore address three questions in this paper: (1) Which of the terrestrial habitats around wetlands are preferred by adults? (2) Does the distance and quality of suitable terrestrial habitats from the natal site affect the occurrence of adults? (3) Which habitat features influence the occurrence of adults in terrestrial habitats?

\section{METHODS}

\section{Study species}

S. depressiusculum occurs in scattered populations from Central Europe to East Asia (Dijkstra \& Lewington, 2006; Kalkman \& Conze, 2015). Its natural water habitats are small, periodically flooded pools and lakes on floodplains of larger rivers. A key factor influencing the occurrence of this species is periodic drying out of aquatic environments (Verbeek, 1998; Schmidt, 2008). After the significant loss of its natural habitats, this species switched to utilizing several types of artificial habitats, including fish ponds and rice fields that are dry during winter (Schmidt, 2008). Although this species is considered as endangered and very rare in Europe, it can be locally very abundant (Kalkman et al., 2010; Sternberg \& Schmidt, 2000). In Central Europe, the larvae begin hatching in mid-April, and adult emergence starts at the beginning of July and continues until mid-August. When the weather is good the flight period ends in mid-October (Sternberg \& Schmidt, 2000, Dolný et al., 2013).

\section{Study sites}

The study area is located in the foothills of the Beskydy Mountains (approximately $300 \mathrm{~m}$ a.s.1.) in the northeast of the Czech Republic. The surrounding landscape is primarily agricultural, with remnants of floodplain forest in the catchment area of the River Sedlnice. Larval development of $S$. depressiusculum was recorded at a single natal site $\left(49^{\circ} 38^{\prime} 05.6^{\prime \prime} \mathrm{N}, 18^{\circ} 06^{\prime} 04.3^{\prime \prime} \mathrm{E}\right)$, one of five farm ponds situated close together. These pond have long been used for rearing the phytophagous cyprinid fish Chondros- toma nasus (Linnaeus), which requires specific management, including periodic draining of the pond in late summer to promote growth of emergent vegetation. This management provides stable conditions similar to those in the natural habitats of $S$. depressiusculum.

Terrestrial habitats around the natal site consist of a mosaic of variously managed agricultural fields, meadows and forests. Agricultural areas (grains, rapeseed) and forests (natural softwood floodplain forests, oak-hornbeam woodlands, spruce monocultures) occupy the majority of the landscape area around the ponds. When sampling occurred some of the agricultural fields had been already harvested or were abandoned, while most of the meadows were managed less intensively. Abandoned fields were left fallow only for a short time and were in an early stage of succession and covered with common annual weeds, while areas abandoned for longer were usually covered with tall vegetation and shrubs.

\section{Data collection}

Habitat preferences of $S$. depressiusculum adults were recorded during the species' main flight period of July-September in 2014 and 2015. At the beginning of this research, we delineated patches of different habitats around the natal site (Fig. 1). During sampling, we repeatedly visited these patches and recorded the abundance of adult individuals. We counted adults between 10:00 and 16:00 CEST only on windless days when cloud cover was less than $20 \%$.

In 2014, we monitored 38 patches at distances of 300 or 500 $\mathrm{m}$ from the natal site. The size of each patch was $10 \times 10 \mathrm{~m}$. For each patch, we recorded habitat (ruderal, arable field, abandoned field meadow, riparian vegetation, forest and forest clearing). In the middle of the season, when all the adults were fully coloured and sex was clearly determinable, the abundance of males and females was estimated separately. In 2015, we randomly selected 9 patches, all at a distance of $300 \mathrm{~m}$ from the natal site, where we repeatedly recorded adult abundance and several environmental factors: vegetation cover (total, tall vegetation, grass and dicotyledonous plants), height of the tall and ground vegetation (average of three random points in each patch), and abundance of potential prey up to $1.5 \mathrm{~cm}$ in size (mainly dipterans, but also other insects and arachnids). Arthropod abundance was sampled along three randomly placed $10 \mathrm{~m}$ transects in each patch using an insect sweep net (10 sweeps along each transect). Insects were generally identified to order level. Table 1 provides a summary of the environmental factors measured in each of the patches and their ranges and medians.

\section{Data analysis}

We used generalized linear mixed models (GLMMs) with negative binomial error distribution and log link to determine the association between adult abundance (response variable), habitat and environmental factors (explanatory variables). In the GLMMs, environmental variables (habitat, distance from natal site, sex, arthropod abundance) were fixed effects and patch visited was a mixed effect. For the analysis, we used the glmer.nb function in the lme4 package (Bates et al., 2014). For post-hoc comparisons between the mean number of adults in each habitat, we used the glht function in the multcomp package (Hothorn et al., 2015) with Tukey's pairwise multiple comparisons of means (Bretz et al., 2010). Statistical significance was established using $\alpha=0.05$. Changes in abundance within a season were illustrated using generalized additive models and an integrated smoothness estimation from the mgcv package (Wood, 2016). All analyses were conducted in R 3.2.2 (R Development Core Team, 2015). 


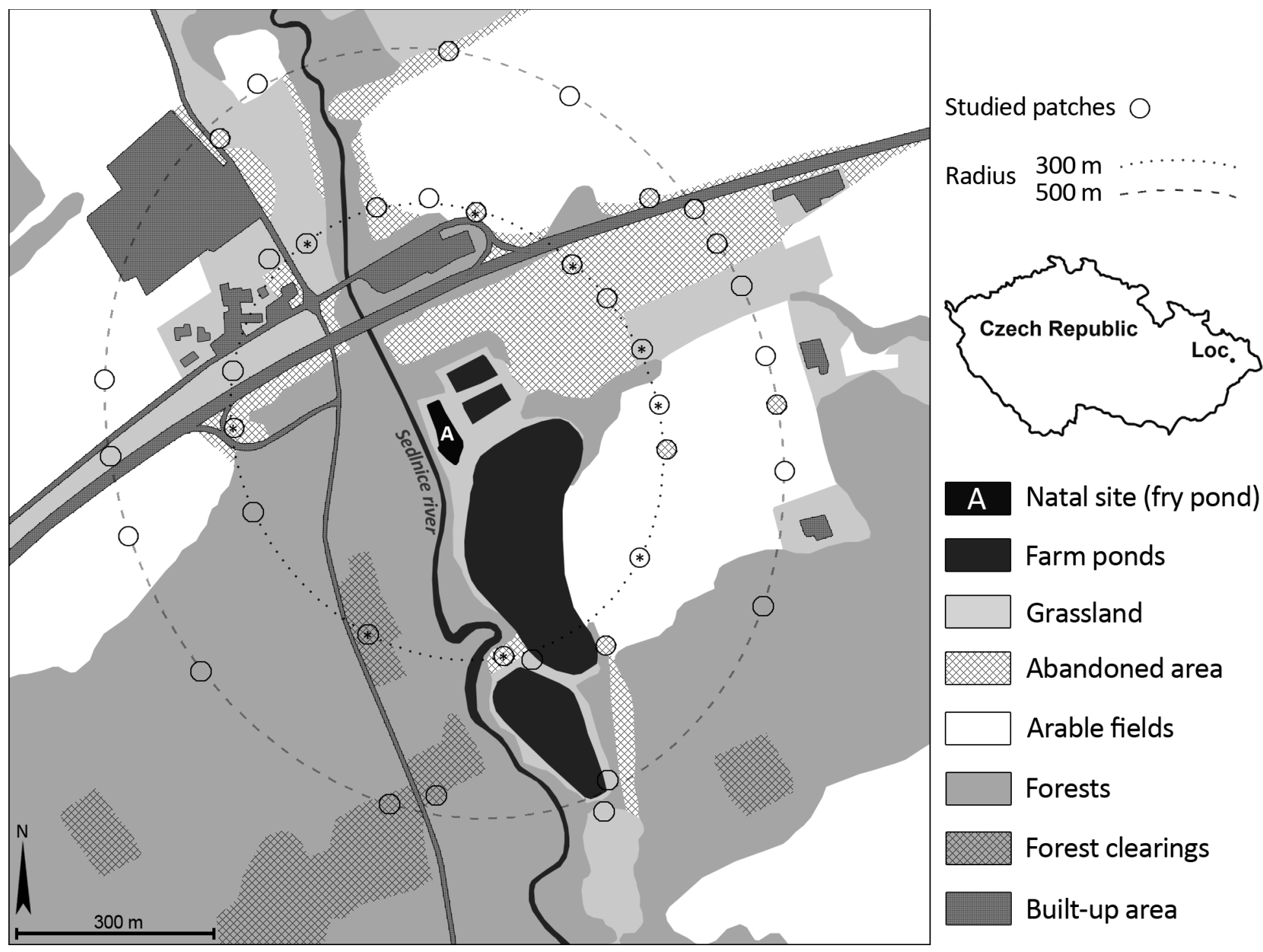

Fig. 1. Location of the patches studied. Patches marked with an asterisk were monitored in 2015.

\section{RESULTS}

In 2014 and 2015, we recorded a total 2,022 S. depressiusculum adults. Habitat preferences of the adults were recorded throughout their occurrence, with the highest abundance in the patches recorded shortly after emergence and then decreasing throughout the season (Fig. 2). The GLMMs revealed that adult abundance was significantly associated with habitat $\left(\chi^{2}=232.015\right.$, df $\left.=6, P<0.001\right)$ and distance from the natal site $\left(\chi^{2}=7.001, \mathrm{df}=1, P=\right.$ $0.008)$. Adults were most abundant in patches with riparian vegetation. In a typical terrestrial environment, adults occurred mainly in abandoned fields, meadows and forest clearings. Imagoes avoided fields with crops and those covered with ruderals and no adults were recorded in forests (Fig. 3). Habitat preferences of adults were not affected

Table 1. Summary of environmental factors measured.

\begin{tabular}{lcc}
\hline Habitat factors & Range & Median \\
\hline Total cover of vegetation (\%) & $5-100$ & 92 \\
Cover of tall vegetation (\%) & $0-90$ & 35 \\
Cover of grass (\%) & $0-95$ & 42 \\
Cover of dicotyledonous plants (\%) & $0-85$ & 55 \\
Height of tall vegetation (cm) & $0-155$ & 60 \\
Height of ground vegetation (cm) & $3-100$ & 40 \\
Abundance of arthropods & $0-474$ & 82 \\
Abundance of dipterans & $0-320$ & 12 \\
\hline
\end{tabular}

by the distance of the patches from the natal site (habitat-distance interaction: $\chi^{2}=6.940, \mathrm{df}=6, P=0.326$ ), but their abundance was significantly lower in the more remote patches.

During sampling in 2014, we recorded a total of 542 males and 172 females. Distribution of adult males and females was also associated with habitat $\left(\chi^{2}=62.5\right.$, df $=$ $1, P<0.001)$, but males and females did not differ in their preferences for particular habitats (sex-habitat type interaction: $\left.\chi^{2}=11.7, \mathrm{df}=6, P=0.069\right)$. Moreover, the effect of distance from natal site on the abundance of adult males and females did not differ significantly $\left(\chi^{2}=3.451, \mathrm{df}=1\right.$, $P=0.063$ ).

Adult abundance was not associated with the location of individual patches in the area (e.g. the presence of ponds near the patch) (Fig. 4). In other words, the occurrence of adults was affected primarily by the patches' specific microhabitat conditions. The number of adults was significantly affected by the total cover of vegetation $\left(\chi^{2}=7.862\right.$, $\mathrm{df}=1, P=0.005)$, cover of tall vegetation $\left(\chi^{2}=17.215, \mathrm{df}\right.$ $=1, P<0.001)$ and abundance of arthropods $\left(\chi^{2}=32.59\right.$, df $=1, P<0.001)$. The other factors associated with microhabitats (especially vegetation) had no significant effects. In addition, the abundance of the species studied was not associated with the abundance of any particular insect order. 

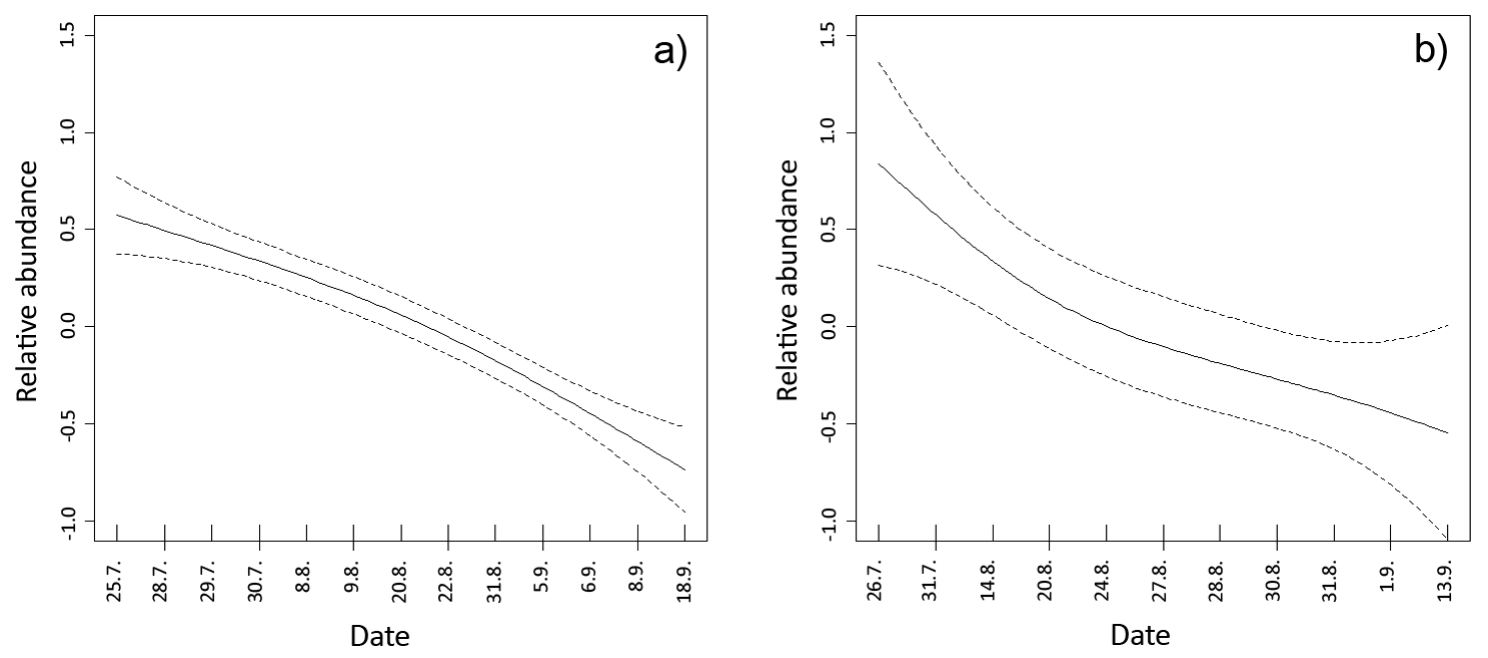

Fig. 2. Seasonal changes in adult abundance recorded in 2014 (a) and 2015 (b).

\section{DISCUSSION}

Based on our results, we conclude that adults of $S$. depressiusculum prefer terrestrial patches with specific properties. Adults respond positively to habitats with a high cover of vegetation and suitable vegetation structure. Such features are only associated with certain terrestrial habitats such as abandoned fields, extensively used meadows, some areas with ruderals or forest clearings. In intensively farmed agricultural landscapes the availability of such patches may be limited and could consequently influence the abundance and distribution of this species. From a life cycle perspective, the quality of terrestrial environments can therefore be as important as that of the aquatic environment necessary for larval development.

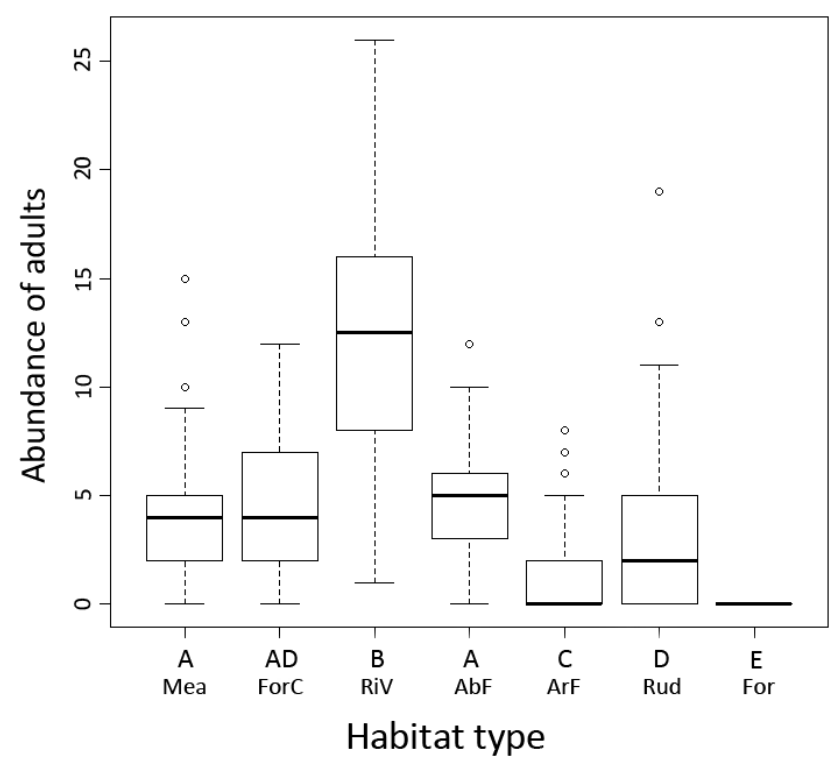

Fig. 3. Abundance of adults recorded in each habitat. Mea - meadow; ForC - forest clearing; RiV - riparian vegetation; AbF - abandoned field; ArF - arable field; Rud - area with ruderals; For - forest. Letters above abbreviations indicate significant differences in the adult abundances recorded in the different habitats based on a post-hoc Tukey's pairwise multiple comparisons of means.
Adult individuals were associated especially with riparian vegetation, but away from ponds they utilized only a fraction of the available terrestrial habitats. High adult density in a riparian zone is a common phenomenon in dragonflies because most activities associated with their reproduction take place in the immediate surroundings of aquatic habitats (e.g. Corbet, 1999; Suhling et al., 2015). Adults used riparian vegetation growing along the embankments of intensively managed ponds (not their natal site) for pairing and copulation. Littoral zone in the vicinity of this vegetation was also used for oviposition (pers. obs.). However, these ponds are not suitable for larval development and could be regarded as ecological traps (see Šigutová et al., 2015). In the surrounding terrestrial landscape, adults preferred abandoned fields, meadows and forest clearings and clearly avoided arable fields, forests, and some areas with ruderals. This is similar to the results of Dolný et al. (2014), who note that even patches of terrestrial habitats

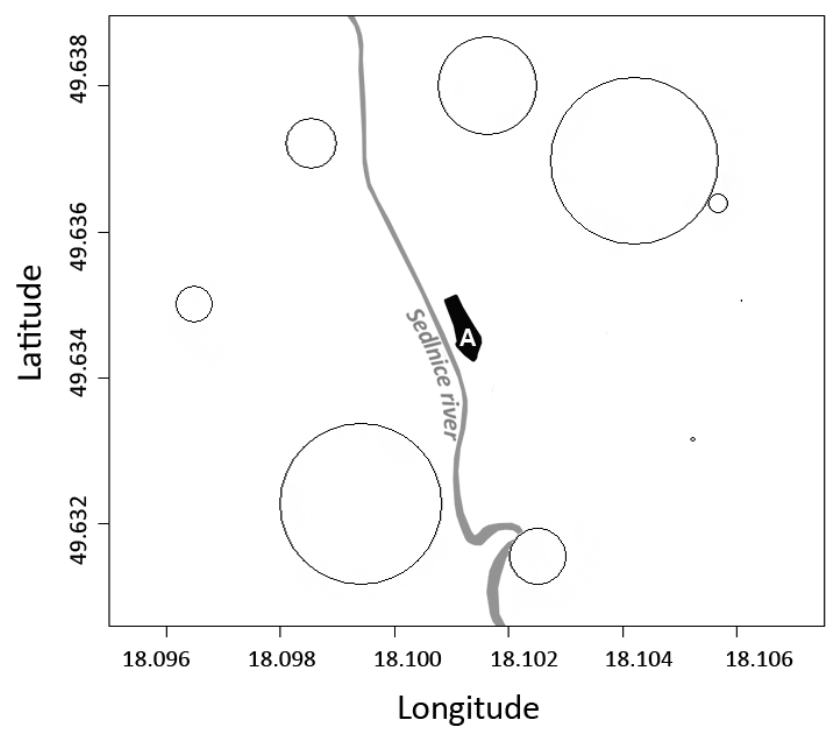

Fig. 4. Effect of patch location on abundance of adults in 2015. Circle size indicates the relative average abundance of adults in each patch. The natal site is located in the middle (A). 
within an agricultural matrix could constitute a mosaic of preferred and non-preferred habitats for dragonflies.

Preference of $S$. depressiusculum for specific terrestrial habitats could be associated especially with vegetation structure. It is unlikely that adult odonates are associated with particular species of plants, as are some pollinators and herbivores, but more likely they respond to such specific vegetation properties as structure and density $(\mathrm{Bu}-$ chwald, 1992; Foote \& Hornung, 2005). Adults of $S$. depressiusculum responded positively to the cover of tall vegetation but not to the height of the vegetation, as was expected. Dense vegetation provides suitable shelters and opportunities for foraging (Sternberg \& Buchwald, 2000; Wildermuth, 2012). In addition, tall vegetation was used primarily as perching sites (pers. obs.), which is typical of the sit-and-wait predators of the genus Sympetrum (Corbet $\&$ May, 2008). Within the area studied, habitats with a suitable vegetation structure were abandoned fields, extensively managed meadows and forest clearings. Homogeneous patches without structured vegetation, which are typically avoided by adults, included arable fields, intensively managed hay meadows and some areas with ruderals. Large differences in the adult abundance recorded in different patches of ruderals were apparently associated with their variability in vegetation structure, as several patches of ruderals were colonized by an invasive plant (e.g. Solidago sp.), which formed dense, unstructured vegetation.

Although adult dragonflies' generally forage more frequently in areas with a higher abundance of potential prey (Corbet, 1999; Kirkton \& Schultz, 2001), there was no association between the abundance of adults recorded in this study and the occurrence of any insect order, such as dipterans, which are considered to be the main prey of dragonflies (Corbet, 1999; Olberg et al., 2000). This indicates that the positive correlation between the abundance of $S$. depressiusculum and all arthropods could be mainly due to both groups preferring more structured vegetation (e.g. Zahn et al., 2010). It is likely, therefore, that the availability of prey in certain habitats does not primarily affect the habitat preferences of the species studied. However, prey density may be significant, especially for territorial species and other species that utilize only the habitats occurring in the immediate vicinity of an aquatic habitat.

\section{Management implications}

Currently, $S$. depressiusculum is one of the most endangered species of dragonfly occurring in Central Europe. It is also worrying that the majority of the Central European populations of this species occur in artificial aquatic habitats, such as fishponds (Kalkman et al., 2010). Moreover, some of these habitats are situated in intensively managed, homogeneous agricultural landscapes. We suggest that terrestrial habitats could be as important as aquatic habitats for population viability and consequently efforts to conserve this species should not only focus on the larval environment but also consider terrestrial habitats surrounding the natal site. Our results indicate that for their routine activities $S$. depressiusculum adults utilize primarily habitats with heterogeneously structured vegetation. It is evident from our findings that effective conservation management should concentrate on maintaining a heterogeneous landscape such as by leaving several fields fallow, use of extensively managed grazing, or maintenance of extensively managed hay meadows (mowed twice annually). Such land use would provide a suitable vegetation structure for this dragonfly.

It is widely assumed that adult odonates avoid recently mown habitats (Sternberg \& Sternberg, 2004; Wildermuth, 2012; Dolný et al., 2014), but very little is known about the direct effect on adult mortality of harvesting. As $S$. depressiusculum adults are relatively weak fliers (Sternberg \& Schmidt, 2000; Dolný \& Holuša, 2008) and individuals aggregate in certain patches, mowing or harvesting at the wrong time (e.g. during cloudy or cold weather when adults are inactive) could significantly increase mortality. Therefore, the first mowing of meadows should be done before the emergence of adults (at the beginning of July) and the last at the end of their occurrence (mid-September). An alternative is to maintain mosaic-like mowing regimes.

ACKNOWLEDGEMENTS. This paper was written as part of an Institute of Environmental Technologies project. Financial support through Project CZ.1.05/2.1.00/03.0100 (IET) financed by the Structural Funds of the European Union and Project LO1208 of the National Programme for Sustainability I of the Czech Republic, as well as support from the Grant Agency of the University of Ostrava (nos. SGS28/PrF/2014 and SGS33/ PrF/2014) and the Czech Science Foundation (No. GA14-04258S) is gratefully appreciated. We would like to thank Milan Konvička from the Czech Fishing Union Př́ibor for helping us with fieldwork.

\section{REFERENCES}

Allen K.A., Le Duc M.G. \& Thompson D.J. 2010: Habitat and conservation of the enigmatic damselfly Ischnura pumilio. J. Insect Conserv. 14: 689-700.

Angelibert S. \& Giani N. 2003: Dispersal characteristics of three odonate species in a patchy habitat. - Ecography 26: 13-20.

Bates D., Maechler M., Bolker B. \& Walker S. 2014: lme4: Linear Mixed-effects Models Using S4 Classes. R Package Ver. 1.1-7. Available online at: http://CRAN.R-project.org/ package $=1 \mathrm{me} 4$.

Bretz F., Hothorn T. \& Westfall P. 2010: Multiple Comparisons Using R. CRC Press, Boca Raton, 205 pp.

BUCHWALD R. 1992: Vegetation and dragonfly fauna - characteristics and examples of biocenological fieldstudies. - Vegetatio 101: 99-107.

Corbet P.S. 1999: Dragonflies: Behavior and Ecology of Odonata. Harley Books, Colchester, 829 pp.

Corbet P.S. \& May M.L. 2008: Fliers and perchers among Odonata: Dichotomy or multidimensional continuum? A provisional reappraisal. - Int. J. Odonatol. 11: 155-171.

D’Amico F., Darblade S., Avignon S., Blanc-Manel S. \& Ormerod S.J. 2004: Odonates as indicators of shallow lake restoration by liming: comparing adult and larval responses. Rest. Ecol. 12: 439-446.

DiJkstra K.-D. (ED.) 2006: Field Guide to the Dragonflies of Britain and Europe including western Turkey and north-western Africa. British Wildlife Publishing, Gillingham, 320 pp.

Dolný A. \& HolušA O. 2008: Sympetrum depressiusculum (Sélys, 1841). In Dolný A., Bárta D., Waldhauser M., Holuša O. \& Hanel L. 2008: Vážky České republiky: ekologie, ochrana a rozšireni. [The Dragonflies of the Czech Republic: Ecology, 
Conservation and Distribution.] ČSOP, Vlašim, pp. 556-561 [in Czech].

Dolný A., Harabiš F., Bárta D., Lhota S. \& Drozd P. 2012: Aquatic insects indicate terrestrial habitat degradation: changes in taxonomical structure and functional diversity of dragonflies in tropical rainforest of East Kalimantan. - Trop. Zool. 25: 141-157.

DolnÝ A., MižIČová H. \& Harabiš F. 2013: Natal philopatry in four European species of dragonflies (Odonata: Sympetrinae) and possible implications for conservation management. $-J$. Insect Conserv. 17: 821-829.

Dolný A., Harabiš F. \& Mižıčová H. 2014: Home range, movement, and distribution patterns of the threatened dragonfly Sympetrum depressiusculum (Odonata: Libellulidae): A thousand times greater territory to protect? - PLOS ONE 9: 1-10.

Foote A.L. \& Hornung C.L. 2005: Odonates as biological indicators of grazing effects on Canadian prairie wetlands. - Ecol. Entomol. 30: 273-283.

Hothorn T., Bretz F. \& Westall P. 2015: multcomp: Simultaneous Inference in General Parametric Models. R Package Ver. 1.4-0. Available online at: http://CRAN.R-project.org/ package $=$ multcomp.

Kalkman V.J., Boudot J.-P., Bernard R., Conze K.-J., De KniJf G., Dyatlova E., Ferreira S., Jović M., Ott J. \& Riservato E. 2010: European Red List of Dragonflies. IUCN \& Publications Office of the European Union, Luxembourg, 38 pp.

KalKman V.J. \& Conze K.-J. 2015: Sympetrum depressiusculum (Sélys, 1841). In Boudot J.P. \& Kalkman V.J. (eds): Atlas of the Dragonflies and Damselflies of Europe. KNNV, Utrecht, pp. 295-297.

KIRKTON S.D. \& SchUltz T.D. 2001: Age-specific behavior and habitat selection of adult male damselflies, Calopteryx maculata (Odonata: Calopterygidae). - J. Insect Behav. 14: 545-556.

KUTCHER T.E. \& BRIED J.T. 2014: Adult Odonata conservatism as an indicator of freshwater wetland condition. - Ecol. Indic. 38: $31-39$.

Moore N.W. (ed.) 1997: Dragonflies - Status Survey and Conservation Action Plan. IUCN/SSC Odonata Specialist Group. IUCN, Gland and Cambridge, 28 pp.

Olberg R.M., Worthington A.H., Fox J.L., Bessette C.E. \& Loosemore M.P. 2004: Prey size selection and distance estimation in foraging adult dragonflies. - J. Comp. Physiol. (A) 191: 791-797.

Orians G.H. \& Wittenberger J.F. 1991: Spatial and temporal scales in habitat selection. - Am. Nat. (Suppl.) 137: 29-49.

R Development Core Team 2015: R: A Language and Environment for Statistical Computing. R Foundation for Statistical Computing, Vienna. Available online at http://www.R-project. org/

RaAb R., Chovanec A. \& Wiener A.K. 1996: Aspects of habitat selection by adult dragonflies at a newly created pond in Vienna, Austria. - Odonatologica 25: 387-390.

RaAb R., Chovanec A. \& Pennerstrorfer J. 2007: Libellen Österreichs. Springer, Wien/New York, 343 pp.
RouQuette R.J. \& THOMPSON D.J. 2007: Roosting site selection in the endangered damselfly, Coenagrion mercuriale, and implications for habitat design. - J. Insect Conserv. 11: 187-193.

Schmidt E.G. 2008: Sympetrum depressiusculum (Selys, 1841), a southern continental dragonfly depending on artificial habitats in Atlantic northwestern Germany (state of NorthrhineWestphalia) (Anisoptera: Libellulidae). — Notul. Odonatol. 7: $5-10$.

ŠIgUTOVÁ H., ŠIgUT M. \& DolnÝ A. 2015: Intensive fish ponds as ecological traps for dragonflies:an imminent threat to the endangered species Sympetrum depressiusculum (Odonata: Libellulidae). - J. Insect Conserv. 19: 961-974.

Sternberg K. \& Buchwald R. (eds) 2000: Die Libellen BadenWürttembergs. Band 2: Großlibellen (Anisoptera). Eugen Ulmer, Stuttgart, $712 \mathrm{pp}$.

Sternberg K. \& Schmidt B. 2000: Sympetrum depressiusculum (Sélys, 1841) Sumpf-Heidelibelle. In Sternberg K. \& Buchwald R. (eds): Die Libellen Baden-Württembergs. Band 2: Großlibellen (Anisoptera). Eugen Ulmer, Stuttgart, pp. 534-548.

Sternberg K. \& Sternberg M. 2004: Change of species composition and increased migration rate of dragonflies due to cutting of adjacent meadows of two running waters (Odonata). - $\mathrm{Li}$ bellula 23: 1-43 [in German, English abstr.].

Stoks R. \& Córdoba-Aguilar A. 2012: Evolutionary ecology of Odonata: A complex life cycle perspective. - Annu. Rev. Entomol. 57: 249-265.

Suhling F., Sahlén G., Gorb S., Kalkman V.J., Dijkstra K.-D. \& van Tol J. 2015: Order Odonata. In Thorp J. \& Rogers D.C. (eds): Ecology and General Biology: Thorp and Covich's Freshwater Invertebrates. Elsevier Academic Press, Amsterdam, pp. 893-932.

VERBEEK P.J.M. 1998: The habitat of Sympetrum depressiusculum in North-western Europe and its future in The Netherlands. Brachyton 3: 3-11 [in Dutch, English abstr.].

WARD L. \& MiLL P.J. 2005: Habitat factors influencing the presence of adult Calopteryx splendens (Odonata: Zygoptera). Eur. J. Entomol. 102: 47-51.

Watts P.C., RouquetTe J.R., SACCheRI I.J., Kemp S.J. \& Thompson D.J. 2004: Molecular and ecological evidence for small-scale isolation by distance in an endangered damselfly, Coenagrion mercuriale. - Mol. Ecol. 13: 2931-2945.

Wildermuth H. 2012: Extensively used meadows as habitat for maturation, forage and copulation of Coenagrion puella and Enallagma cyathigerum (Odonata: Coenagrionidae). - Libellula 31: 223-235 [in German, English abstr.].

Wood S. 2016: mgcv: Mixed GAM Computation Vehicle with GCV/AIC/REML Smoothness Estimation. $R$ Package Ver. 1.8-5. Available online at: http://CRAN.R-project.org/ package $=$ mgcv.

Zahn A., Englmaier I. \& Drobny M. 2010: Food availability for insectivores in grasslands - arthropod abundance in pastures, meadows and fallow land. - Appl. Ecol. Environ. Res. 8: 87-100.

Received March 31, 2016; revised and accepted July 4, 2016 Published online September 13, 2016 